\title{
ERNIE HAWK: THE THIRD CAREER
}

\section{Society's Executive Secretary pulls back to contemplate science, technology and society}

The Materials Research Society is essentially operated by volunteers. Almost from its inception, however, much of its administrative support has been provided by the Materials Research Laboratory of The Pennsylvania State University. Throughout those years, the man on the spot has been Ernest M. Hawk.

Ernie Hawk is the Society's Executive Secretary. As the chief of the MRS General Secretariat, Ernie assists the organizers of the Society's key events - the technical meetings and arranges the thousands of details that make them possible, from preparing the Preliminary Announcement to registering participants. $\mathrm{He}$ formalizes negotiations with funding agencies, sees that information is mailed to members, assists the officers and committees in their work, maintains the Society's archives and fields the correspondence that joins us all together.

Ernie wears many other hats, as well. $\mathrm{He}$ is Manager of Science and Society Programs for Penn State. This involves coordination of activities relating university research to industrial research and development. The principal vehicles are the Industrial Coupling Program of Penn State's Materials Research Laboratory; the Commonwealth of Pennsylvania's Technical Assistance Program, and the studies and programs of the Materials Advisory Panel of the Pennsylvania Governor's Science Advisory Committee and the Pennsylvania Science and Engineering Foundation.

As Manager of Penn State's Science, Technology and Society Program, Ernie coordinates activities for students and faculty that bridge technical and humanistic disciplines. These includes interdisciplinary courses and research, symposia, seminars, a guest-lecture series and development of teaching resources for the Program in both print and video formats. He also is a former member of the board, officer and special consultant to the Kirkridge Retreat and Study Center in Bangor, $\mathrm{Pa}$., and a member of the board of Community Alternatives in Criminal Justice, State College, Pennsylvania.

For some time, Ernie has been gently prodding the MRS to find a way to liberate him to pursue his central interest - the study of the moral implications for human life that science and technology create. With the emerging centralization of the Society's administrative apparatus, the Society is able to accede, with an understandable reluctance, to Ernie's wishes.

An ordained minister in the United Church of Christ, Ernie took his B.A. in Philosophy and Religion from Muhlenberg College, his B.D. from Lancaster (Pa.) Theological Seminary, and his M. Ed. in Higher Education from Penn State, concentrating in Science and Religion. Until 1967, he was pastor of several United Church of Christ congregations.

"Twenty years ago I got interested in some of the moral and ethical questions raised by science and technology," Ernie says. "I remember - this was at the time of the early development of computer technology - reading Norbert Wiener's book, The Human Use of Human Beings, which raised questions about the meaning of a society that is becoming increasingly computerized.

"Also, I was affected by Stanley Kubrick's movie, Dr. Strangelove, which showed the problems raised in trying to control the use of weapons' technology. That movie was unsettling to me, and I began to wonder about how we do control the use of technology."

After 20 years of pastoral ministry, Ernie says, "I was ready for a new challenge." (He adds, "Now I'm almost at the end of another 20-year span; maybe I work in those cycles.") He

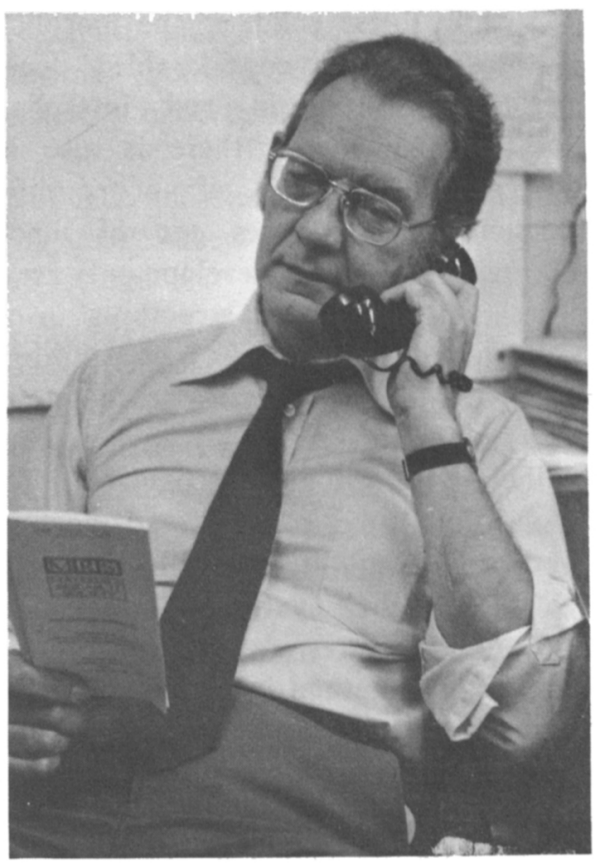

ERNIE HAWK

took a "non-technical and secular" job at Penn State, where his burgeoning interest in religion and science led him to Harold K. Schilling, head of the department of physics and dean of the graduate school, "who was, in his later years, pursuing the area of science and religion." He also joined forces with one of the founders of the MRS, Rustum Roy, whom Ernie describes as "very much a pioneering thinker in the area of science, technology and society."

This culminated eight years ago in Ernie's selection to help lead Penn State's STS (Science, Technology and Society) program, which he has been doing when he hasn't been tending to the administrative requirements of the MRS. He is presently easing himself away from those duties "to get back into this STS area more. The program has potential but it needs more energy, thought and work than I've been able to give it up to now."

"Since the Second World War," Ernie

[Continued on Page 18] 


\section{HIRSCH}

[Continued from Page 4]

Cavendish Laboratory, Cambridge, taking his M.A. in 1950 and his Ph.D. a year later.

At the Cavendish Laboratory, Hirsch carried out research on the relation between microstructure and the mechanical properties of metals and alloys. After studying first the detailed structure of metals by means of fine beam X-rays, he and his colleagues developed in 1956 an electron transmission microscope technique whereby individual crystal lattice defects, called dislocations, can be resolved and their structure, arrangement and interactions studied. Professor Hirsch and his research group developed the basic theory of contrast of electron microscope images of lattice defects and applied this technique to the study of a number of

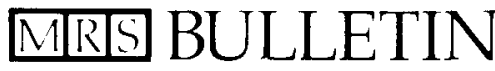

\section{VOLUME VIII NUMBER 5}

The Materials Research Society Bulletin is published bi-monthly by the Materials Research Society for its members and others interested in materials science. Correspondence and submissions are invited. They should be brief and typewritten (double-spaced), and the author's affiliation must be indicated. Address all material to the Editor.

$$
\begin{gathered}
\text { President } \\
\text { H.J. LEAMY } \\
\text { Bell Laboratories } \\
\text { First Vice President } \\
\text { C.W. WHITE } \\
\text { Oak Ridge National Laboratory } \\
\text { Second Vice President } \\
\text { E.N. KAUFMANN } \\
\text { Lawrence Livermore Laboratory } \\
\text { Secretary } \\
\text { R.L. SCHWOEBEL } \\
\text { Sandia National Laboratory } \\
\text { Treasurer } \\
\text { K.C. TAYLOR } \\
\text { GM Research Laboratories } \\
\text { Executive Director } \\
\text { JOHN B. BALLANCE } \\
\text { Materials Research Society } \\
\text { 9800 McKnight Road, Suite } 327 \\
\text { Pittsburgh, PA I5237 } \\
\text { (4I2) } 367-3003 \\
\text { Editor } \\
\text { T.G. MIDDLETON } \\
\text { P.O. Box K } \\
\text { Short Hills, NJ 07078 }
\end{gathered}
$$

basic problems in dislocation theory, and associated with the use of metals and alloys, including their strength, work-hardening, fatigue and annealing behavior.

\section{Teaching Appointments}

In 1959 Hirsch married Mabel Anne Kellar (nee Stephens), widow of James Noel Kellar. That year he was appointed Lecturer in Physics at Cambridge, and a year later made a Fellow of Christ's College, Cambridge. (In 1978 Christ's College named him an Honorary Fellow.) $\mathrm{He}$ was appointed Reader in Physics at Cambridge in 1964, a position he retained for two years.

After coming to Oxford in 1966 as Head of the Department of Metallurgy and Science of Materials, he turned his attention to the mechanical properties of dispersion hardened alloys, the mechanism of climb of dissociated dislocations, the nature of defects in semiconductors and, more recently, to the effect of doping on the mechanical properties of semiconductors and ceramics, as well as to the mechanisms of work hardening in ordered alloys.

\section{Honors}

As indefatigable with his pen as his microscope, Hirsch published scores of articles in learned journals. In 1965 his Electron Microscopy of Thin Crystals was issued, and quickly became a standard. Already a Fellow of the Royal Society and the recipient of the Rosenhain Medal of the Institute of Metals and the C.V. Boyes Prize of the Institute of Physics and Physical Society, Hirsch began to be showered with honors: honorary doctorates from such schools as Newcastle, East Anglia, Northwestern and City universities; the Clamer Medal of the Franklin Institute, which also made him a Life Fellow, Helsinki's Wihuri International Prize, the Hughes Medal of the Royal Society, the Platinum Medal of the Metals Society, the Royal Medal of the Royal Society and the A.A. Griffith Silver Medal of the Materials Science Club; and Fellowships and Honorary Fellowships in such societies as the Institute of Physics, Institution of Metallurgists, Royal Microscopical Society and the Japan Society of Electron Microscopy. In 1975 he was

\section{ERNIE HAWK}

\section{[Continued from Page 15]}

says, "technology has had very rapid growth, without much thought or direction. It's been an unhealthy and unwholesome growth in many ways. I think some of our chickens are coming home to roost now, in the area of the environment, certainly. And very particularly in the area of international power politics, technology is a very unsettling factor. Somewhat belatedly, I think we're recognizing the need to come to terms with some of these human issues about technology, which we have been sweeping under the rug for the last 25 years.

"What does it mean to be human as more and more technological changes are made in the person - genetic engineering, organ transplants, the extension of life by artificial means? Problems attach to this; an aging population, for one. What does all this technological change say about the meaning of life? These are some of the human questions that need to be considered and addressed."

These studies will constitute Ernie's third career. The rapid growth of the MRS created administrative tangles that Ernie has devoted a substantial fraction of his second to straightening out. As he strikes out anew, Ernie Hawk takes with him the Materials Research Society's deep appreciation, respect and best wishes.

honored by his nation and made Knight Bachelor.

Sir Peter in 1982 was appointed Chairman of the United Kingdom Atomic Energy Authority. His work in metallurgy had led to the assessment of the integrity of pressurized water reactors, and a unique understanding of the damage caused by irradiation in nuclear reactors.

The Materials Research Society is proud to recognize with its Arthur Von Hippel Award a scientist of the stature of Professor Sir Peter Hirsch. He joins an elite group whose common bond is the gift of inspiration made real through training and industry. 